\title{
THE KNEE-JERK AFTER SECTION OF THE SPINAL CORD.'
}

\author{
BI" EDWIARD T. REICHEKT, M.D., \\ Protessor of Phy-siology, University ol Pennsylvania.
}

\begin{abstract}
INCE Westphal and Erb introduced the knee-jerk, or
D the patellar-tendon-reflex, or knee phenomenon, as it is sometimes called, as a diagnostic factor it has assumed a position of questionable value, and of late years generally been looked upon with increasing distrust. Why this should be seems evident in the extensive and acute observation demanded in its study; in the uncertain character of our knowledge regarding its true nature and its full significance; and in the almost entire absence of information of the conditions, normal and abnormal, which affect it.
\end{abstract}

While the nature of the knee-jerk is not definitely known, there can be no doubt that its manifestation depends upon the functional integrity of a reflex arc connecting the quadriceps femoris with cerebro-spinal centres, and that the essential part of this is found in groups of cells constituting the proper centres in the spinal cord. Other things being equal, the extent of reaction when the tendon is struck depends: first, upon the condition of the reflex arc, which when affected, as in tabes dorsalis, where the sensory paths are interfered with, is diminished or lost, or as in lateral sclerosis, where perhaps the spinal cells are indirectly excited, is exaggerated; second, upon the degree of tension placed upon the patellar ligament, the reaction increasing with the tension up to a certain point; third, upon the strength of blow, the reaction increasing with the degree of stimulus.

Should the tendon be repeatedly struck at proper intervals by blows of like strength, the successive reactions will, as a rule, be practically of the same extent, but occasionally more or less distinctly exaggerated or dimin-

1 Read before the American Society of Physiologists, December 28, 1889. 
ished, and, at times, to a remarkable degree. These incidental or unexpected modifications in the average reaction have been the cause of some confusion, and the actual reasons for their occurrence were not apparent until the discovery of Jendréssek ("Deutches Archiv. f. klin. med," Bd. 33, S. 177, 1883) that if the hands were clinched immediately before the tendon was struck the knee-jerk was greater than when the individual was perfectly quiet. While this significant fact does not seem to have been fully appreciated by him, it has fortunately led to investigation in this country, which has been the starting point of observation of rare clinical importance, and which has already thrown much light upon this obscure subject.

Mitchell and Lewis ("Philadelphia Medical News," Feb., I886), and Mitchell (ibid., June, I888) found that any movement, if at all decided, and that a vast range of sensations, if made or perceived simultaneously with the tapping of the tendon, would exaggerate the reflex; and, further, if a galvanic current were passed through the anterior part of the brain it was also increased, probably owing to "a complex effect made up of sensation, motion, emotion, and some other more immediate affections of the brain." In Lombard's studies ("American Journal of Psychology," Oct., 1887) we note most important additions to our knowledge of the variations which occur in the normal knee-jerk. He found that it suffers a diurnal variation, being highest in the morning; is increased after each meal; is diminished by muscular or mental fatigue; is increased by mental activity; is affected by the weather, being in general increased by a fall of temperature and decreased by a rise, rising and falling with the barometer, but not visibly influenced by the direction of the wind, the humidity or electrical potential of the atmosphere. In general, whatever increa ed or diminished the activity of the central nervous system similarly influenced the knee-jerk. Moreover, voluntary movements and sensory irritations, even when not strong enough to cause a reflex, would when synchronous with the blow upon the tendon increase the reflex. Strong emotions, even during sleep when the dreams are vivid, acted simi- 
larly. Thus music, the cry of a child, a knock at the door would affect the degree of reaction.

The fact that the volitional movements, sensations, or emotions must occur simultaneously or slightly antecedent to the tapping of the tendon to reenforce the reaction, led Bowditch and Warren ("Boston Medical and Surgical Journal." May, I888) to make some investigations to determine how the extent of the knee-jerk would be affected by varying the interval of time at which the blow on the tendon followed the volitional movement for reënforcement. As the result of $55 \mathrm{I}$ normal and 624 reënforced knee-jerks in the same individual, they found " that if the blow follows the signal [for a volitional movement] at an interval not greater than 0.4," the reënforcing act increases the extent of the knee-jerk. If the interval exceeds this amount, a diminution of the knee-jerk results. If, however, the interval is prolonged to 1.7 , "the reënforcing act is without effect on the knee-jerk."

Thus we find that the knee-jerk is temporarily modified by many normal conditions, and that it may undergo decided momentary variations through a volitional movement, sensation, or emotion occurring at about the time of the blow upon the tendon, and that the volitional movement may reënforce or inhibit the normal degree of reaction depending upon the time of its occurrence in relation to the time of tapping the ligamentum patella.

In all the instances where incidental reënforcements or inhibitions of the knee-jerk occurred, it seems evident that the mind played an important part, either in the origination of the volitional movement or the emotion, or in the perception of the sensation. It was therefore suggested by Dr. S. Weir Mitchell that experiments be made upon the lower animals, in which the spinal cord was previously cut, to learn if similar alterations could be induced where all cerebral action would be cut off. I accordingly performed twelve experiments on dogs, which were anæsthetized and the cord cut in the lower cervical or upper dorsal region. In all cases the operation was practically bloodless, save one, where the hæmorrhage amounted to less than three 
ounces; and the sections of the cord were complete, as shown by autopsies. Immediately after the section the reflexes are diminished, but in the course of a couple of hours or even less are normal, when the animals may be studied. To accomplish this, the dog is placed upon his side on the table and held gently but firmly by an assistant; the leg is suspended, the tendon struck, and the reaction recorded, as in Lombard's experiments on man. An additional record was also made, by a suitable recordingapparatus, of the time of the application of the reënforcing stimulus and that of the occurrence of the reaction. The stimulus was either mechanical, by strongly pinching the toes of the opposite foot, or electrical, where the electrodes were thrust into the skin of the opposite leg or into the upper part of the peripheral segment of the spinal cord, and an induction-current used of sufficient strength to cause pain when applied to the hands. More or less trouble was experienced in keeping the animals quiet, to prevent a disarrangement of such a complex piece of apparatus and avoid inaccurate records, but with much care it was found in all cases, without exception, that there was never any positive evidence that the knee-jerk was affected in any way by these conjoint excitations, no matter what their true relations were in conjunction with the blow upon the tendon.

These uniform results therefore indicate that the reënforcement or inhibition of the knee-jerk are dependent upon some peculiar influence exerted by the cerebral centres. 